Article

\title{
Electro-polymerization fabrication of PANI@GF electrode and its energy-effective electrocatalytic performance in electro-Fenton process
}

\author{
Jinli Yu ${ }^{\mathrm{a}}$, Tianfu Liu ${ }^{\mathrm{b}}$, Haiyue Liu ${ }^{\mathrm{b}}$, Yi Wang ${ }^{\mathrm{b}, *}$ \\ a The Key Lab of Low-Carbon Chemistry \& Energy Conservation of Guangdong Province, School of Materials Science and Engineering, Sun Yat-sen \\ University, Guangzhou 510275, Guangdong, China \\ ${ }^{\mathrm{b}}$ School of Chemical Engineering and Technology, Sun Yat-sen University, Zhuhai 519082, Guangdong, China
}

\section{A R T I C L E I N F O}

\section{Article history:}

Received 18 August 2016

Accepted 8 September 2016

Published 5 December 2016

\section{Keywords:}

Electrocatalysis

Oxygen reduction reaction

Electro-polymerization

Electro-Fenton

Dimethyl phthalate degradation

\begin{abstract}
A B S T R A C T
An energy-effective polyaniline coated graphite felt (PANI@GF) composite cathode for the electro-Fenton (E-Fenton) process was synthesized through an electro-polymerization method. The electrocatalytic activity of the cathode for the $2 \mathrm{e}^{-}$ORR process was investigated and dimethyl phthalate (DMP) was used as a model substrate to evaluate its performance in the E-Fenton process. The as-prepared PANI@GF composite possessed a three-dimensional porous structure, which is favorable for $\mathrm{O}_{2}$ diffusion, while the large amount of $\mathrm{N}$ atoms in the conductive polyaniline (PANI) enhanced 22- ORR reactivity. The DMP degradation of the E-Fenton system using PANI@GF was significantly enhanced owing to the improvement in ORR performance. The apparent kinetic constant for DMP degradation was $0.0753 \mathrm{~min}^{-1}$, five times larger than that of GF. The optimal carbonization temperature and polymerization time for the preparation of the PANI@GF composite cathode was found to be $900{ }^{\circ} \mathrm{C}$ and $1 \mathrm{~h}$, respectively. Measurement conditions are a crucial factor for proper evaluation of cathode electrocatalytic performance. Accordingly, the $\mathrm{O}_{2}$ flow rate, $\mathrm{Fe}^{2+}$ concentration, and $\mathrm{pH}$ for DMP degradation were optimized at $0.4 \mathrm{~L} / \mathrm{min}, 1.0 \mathrm{mmol} / \mathrm{L}$, and 3.0, respectively. These results indicate that the present PANI@GF composite cathode is energy-effective and promising for potential use as an E-Fenton system cathode for the removal of organic pollutants in wastewater.
\end{abstract}

(C) 2016, Dalian Institute of Chemical Physics, Chinese Academy of Sciences. Published by Elsevier B.V. All rights reserved.

\section{Introduction}

The electro-Fenton process (E-Fenton) [1-4], one of the advanced oxidation processes (AOPs), has been shown to be a promising technology for degrading refractory pollutants in wastewater [5-10]. The process is a simple electrochemical reaction process. First, $\mathrm{H}_{2} \mathrm{O}_{2}$ is generated from the reduction of
$\mathrm{O}_{2}$ through a $2 \mathrm{e}^{-}$process without additional acquisition, shipment, or storage (Eq. 1). Subsequently, $\mathrm{Fe}^{2+}$ is added to the system to react with the $\mathrm{H}_{2} \mathrm{O}_{2}$ to generate hydroxyl radicals $(\cdot \mathrm{OH})$ (Eq. 2). The hydroxyl radicals, which have a high electrode potential (2.8 V vs. standard hydrogen electrode (SHE)), can rapidly non-selectively destroy refractory pollutants [11-13].

$$
\mathrm{O}_{2}+2 \mathrm{H}^{+}+2 \mathrm{e}^{-} \rightarrow \mathrm{H}_{2} \mathrm{O}_{2} \quad 0.695 \mathrm{~V} \text { (vs. SHE) }
$$

\footnotetext{
* Corresponding author. Tel: +86-20-84110930; Fax: +86-20-84113253; E-mail: wangyi76@mail.sysu.edu.cn

This work was supported by the Sino-Greek Science and Technology Cooperation Project (2013DFG62590), the National Natural Science Foundation of China (21575299, 21576300, 21276290), Guangdong Province Nature Science Foundation (2014A030313150), and Guangzhou Science and Technology Plan Project (201607010104).

DOI: 10.1016/S1872-2067(16)62525-1 | http://www.sciencedirect.com/science/journal/18722067 | Chin. J. Catal., Vol. 37, No. 12, December 2016
} 


$$
\mathrm{Fe}^{2+}+\mathrm{H}_{2} \mathrm{O}_{2} \rightarrow \cdot \mathrm{OH}+\mathrm{OH}^{-}+\mathrm{Fe}^{3+}
$$

In the E-Fenton process, $\mathrm{H}_{2} \mathrm{O}_{2}$ is first generated at the cathode through the $2 \mathrm{e}^{-}$oxygen reduction reaction (ORR) process $[14,15]$. So, improvement of the efficiency of ORR for $\mathrm{H}_{2} \mathrm{O}_{2}$ production is crucial for E-Fenton systems [16]. The cathode material can greatly influence the mechanism and kinetics of ORR $[17,18]$. At present, carbonaceous materials have been widely investigated for their excellent ORR reactivity, with advantages such as high overpotential for hydrogen evolution, non-toxicity, low cost, and good stability. Carbonaceous materials such as graphite, carbon felt, graphite felt, carbon sponge, activated carbon fiber, and carbon-polytetrafluoroethylene (PTFE) composite electrodes are widely used in E-Fenton systems [19-25]. Among them, graphite felt (GF), already a commercialized cathode material, shows promising advantages such as a 3D interconnected structure that provides abundant active sites and rapid mass-transfer, outstanding anti-corrosion resistance, mechanical integrity in flexible electrodes, and ease of manufacture for large-scale applications [21]. Accordingly, GF has attracted great attention in the electrocatalysis field. Because the kinetics of the electrochemical process of ORR on carbon is complicated and quite sensitive to surface properties, various pretreatment methods have been introduced to make carbonaceous materials more efficient for $\mathrm{H}_{2} \mathrm{O}_{2}$ production and the E-Fenton process. As reported, the electrocatalytic activity of GF can be significantly enhanced through surface modification [26].

Recently, it has been widely reported that N-doped carbon materials possess high ORR activity, attracting much attention for ORR electrocatalysts for fuel cell applications. Among them, electrocatalysts synthesized using non-precious metals and polymer precursors containing nitrogen atoms have shown promising activity and unique durability for ORR [27-29]. Polyaniline (PANI), which contains a favorable combination of aromatic rings connected via nitrogen-containing groups, is widely used as both an $\mathrm{N}$ and $\mathrm{C}$ precursor. For example, Wu et al. [30] reported electrocatalysts with high ORR performance derived from iron, cobalt, and PANI. Kim et al. [31] reported $\mathrm{NH}_{3}$-activated $\mathrm{Fe} / \mathrm{PANI}$ composites for ORR. However, until now no study has been devoted to the performance of PANI derived material in an E-Fenton system.

In the present investigation, we focused on the fabrication and evaluation of a polyaniline coated graphite felt (PANI@GF) composite for the electrocatalytic reduction of oxygen and subsequently as an E-Fenton cathode. The PANI@GF composite was synthesized through a novel electro-polymerization method. Both the surface chemistry and structural properties of the composite were studied, and its electrocatalytic activity for ORR was investigated. Herein, dimethyl phthalate (DMP) was used as a model substrate to evaluate the performance of PANI@GF for the E-Fenton process.

DMP, a representative di-alkyl phthalate ester, is widely used as an indispensable additive for plastics to increase their flexibility. The annual world production of plastics is estimated to be around 100 million tons. As a result, a great amount of DMP is drained into the aquatic environment through the disposal of manufacturing wastewater. DMP belongs to the endo- crine-disrupting chemicals, whose ubiquity in the environment has brought great concern to the public and environmental researchers [32,33]. DMP has been listed as a priority pollutant in many countries and is used in the rapid performance assessment of some AOPs, including the E-Fenton reaction.

\section{Experimental}

\subsection{Preparation of PANI@GF}

All chemicals used in this work were of analytical grade. The commercial GF (Hunan Jiuhua Carbon High-Tech Co. Ltd., China) was first degreased with acetone in an ultrasonic bath for $15 \mathrm{~min}$ and then washed with deionized water several times to remove the residual acetone. To synthesize PANI@GF, a GF plate $(2.0 \mathrm{~cm} \times 2.0 \mathrm{~cm})$ was used as the substrate, while a Pt foil $(2.0 \mathrm{~cm} \times 1.0 \mathrm{~cm})$ and a saturated calomel electrode (SCE) were used as the anode and the reference electrode, respectively. A PANI layer was electro-polymerized onto the surface of the GF in an aqueous solution containing $0.2 \mathrm{~mol} / \mathrm{L}$ aniline and 0.75 mol/ $\mathrm{L} \mathrm{H}_{2} \mathrm{SO}_{4}$ by the galvanostatic method at $0.5 \mathrm{~mA} / \mathrm{cm}^{2}$ for $1 \mathrm{~h}$ at room temperature. Next, the plate with PANI layer was subjected to heat treatment at $900^{\circ} \mathrm{C}$ for $3 \mathrm{~h}$ under $\mathrm{N}_{2}$ atmosphere. The heat-treated product was then washed with $0.1 \mathrm{~mol} / \mathrm{L}$ aqueous $\mathrm{H}_{2} \mathrm{SO}_{4}$ several times to remove any unstable and ORR-nonreactive residues. The as-prepared PANI@GF composite was used as the cathode of the E-Fenton system in the following experiments.

\subsection{Physico-chemical characterization of PANI@GF}

The morphology of the PANI@GF was observed using scanning electron microscopy (SEM; Quanta 400F, FEI/Oxford/HKL, Holland and France). X-ray photoelectron spectroscopy (XPS) characterization was performed on an ESCALAB 250 (ThermoFisher Scientific, USA).

\subsection{DMP degradation}

The DMP degradation experiment was carried out in a three-necked cell at a cathodic potential of $0.5 \mathrm{~V}$ (vs. SCE) using PANI@GF or GF as the E-Fenton cathode, Pt foil as the counter electrode, and a SCE as the reference electrode. A $50 \mathrm{mg} / \mathrm{L} \mathrm{DMP}$ solution was prepared in advance. $\mathrm{FeSO}_{4} \cdot 7 \mathrm{H}_{2} \mathrm{O}$ solution was added to the DMP solution and the $\mathrm{pH}$ was adjusted to the required value using dilute sulfuric acid and sodium hydroxide. The reaction started when $\mathrm{H}_{2} \mathrm{O}_{2}$ was electrochemically generated in-situ. After a certain reaction time, $1.00 \mathrm{~mL}$ of the reaction solution was removed from the system and placed in a centrifuge tube containing $0.02 \mathrm{~mL}$ methanol for later analysis.

\subsection{Chemical analysis}

The $\mathrm{H}_{2} \mathrm{O}_{2}$ concentration of the reaction solution was determined using the potassium titanium oxalate method with a UV-VIS spectrophotometer (TU1810, Universal Analysis, Beijing, China). The DMP concentration was measured using a high 


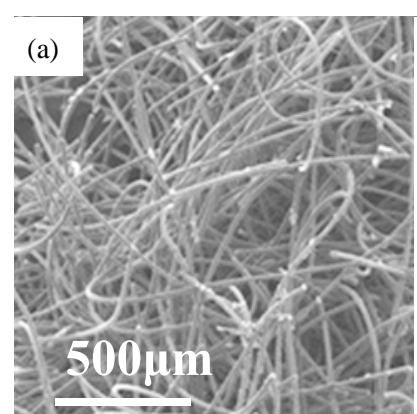

(b)

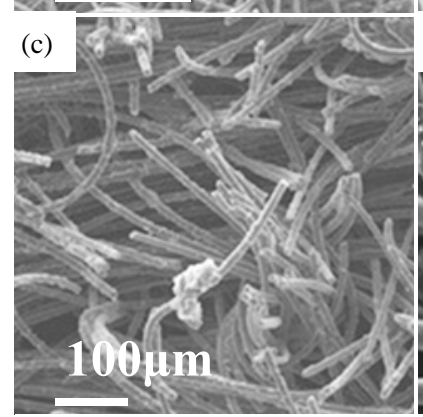

(d)
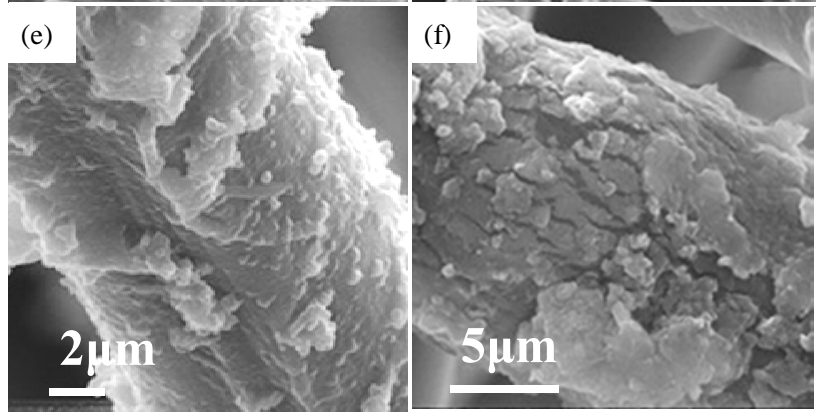

Fig. 1. SEM images of GF (a, b), and PANI@GF (c, d, e, f).

performance liquid chromatograph (HPLC; LC 2140, Techcomp, Shanghai, China) equipped with a reverse phase column (XT erra MS C-18, $5 \mu \mathrm{m}$, Waters, USA) and a UV detector. The mobile phase was a mixed solution of $50 \%$ acetonitrile and $50 \%$ water $(V / V)$, and the detection wavelength was set to $276 \mathrm{~nm}$. The total organic carbon (TOC) concentration was determined with a TOC/TNb analyzer (Vario TOC cube, Elemental, Germany) using the standard non-purgeable organic carbon (NPOC) method.

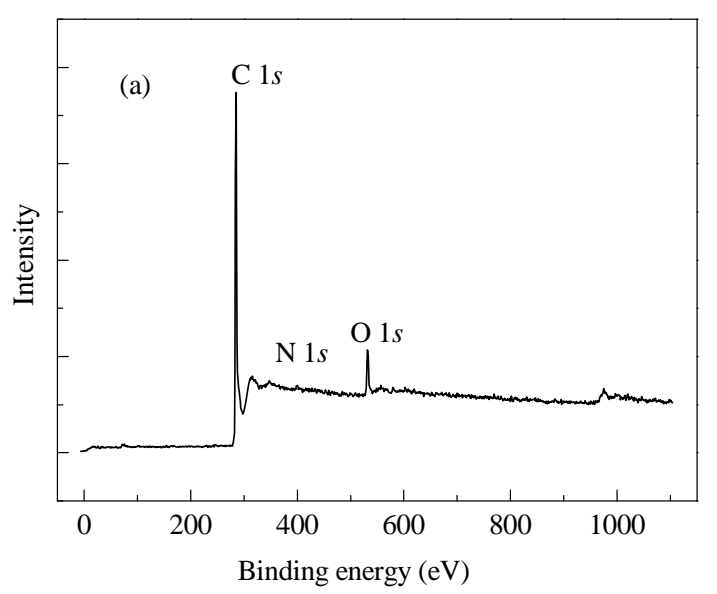

\section{Results and discussion}

\subsection{Physico-chemical properties of PANI@GF}

The morphology and composition of the electro-polymerized GF were investigated by SEM and XPS. Fig. 1(a) and (b) show that the untreated graphite felt had a 3D porous structure stemming from its overlapped carbon fibers. The surface of the carbon fibers was very smooth with occasional small attached lumps. These attachments may have been some impurities and could be eliminated through pretreatment with acid and alkali. Fig. 1(c) and (d) show that after electro-polymerization, polyaniline was well deposited on the carbon fibers, making their surface rough. The covering itself was loose and had a porous structure, as demonstrated in Fig. 1(e) and (f), which was expected to help enhance the electrochemically active area and be beneficial for the diffusion of $\mathrm{O}_{2}$, thereby enhancing the ORR mass-transfer process and performance and then the E-Fenton performance.

The atomic configuration and stoichiometric composition of PANI@GF were analyzed by XPS. The atomic content of the PANI@GF was calculated from the integrated peak area of the $\mathrm{C} 1 s, 01 s$, and N1s signals divided by their atomic sensitivity factor. The XPS survey scan revealed that the $\mathrm{N}$ and $\mathrm{O}$ content of the composite was 1.96 at.\% and 7.91 at.\%, respectively. The atomic 0 content of PANI@GF was decreased compared with that of the untreated GF (13.57 at.\%), indicating the depletion of oxygen functional groups, as demonstrated in Fig. 2(a). The N1s spectra depicted in Fig. 2(b) show that the PANI@GF composite contained four different kinds of $\mathrm{N}$ coordinations: pyridinic $\mathrm{N}$, amine $\mathrm{N}$, pyrrolic $\mathrm{N}$, and graphitic $\mathrm{N}$. The content of pyridinic $\mathrm{N}$ and pyrrolic $\mathrm{N}$ in PANI@GF was obviously higher than the others. These results confirm that, as well as the macroscopic 3D porous structure of $\mathrm{GF}$, the material also had a micro three-dimensional porous structure, and that $\mathrm{N}$ atoms were successfully doped into the GF surface.

\subsection{E-Fenton performance of PANI@GF}

As shown in Fig. 3, it took $2 \mathrm{~h}$ for GF to completely degrade DMP, but only 45 min for PANI@GF to completely degrade

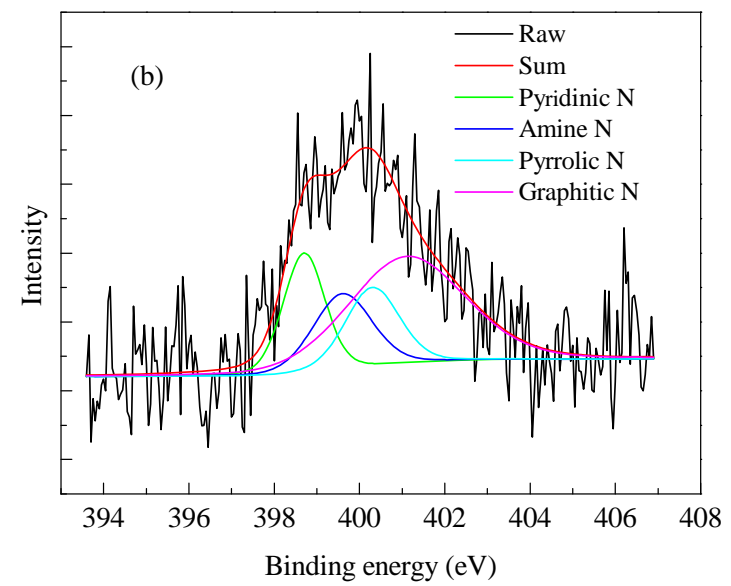

Fig. 2. XPS spectra of PANI@GF. (a) XPS survey; (b) N1s spectra. 

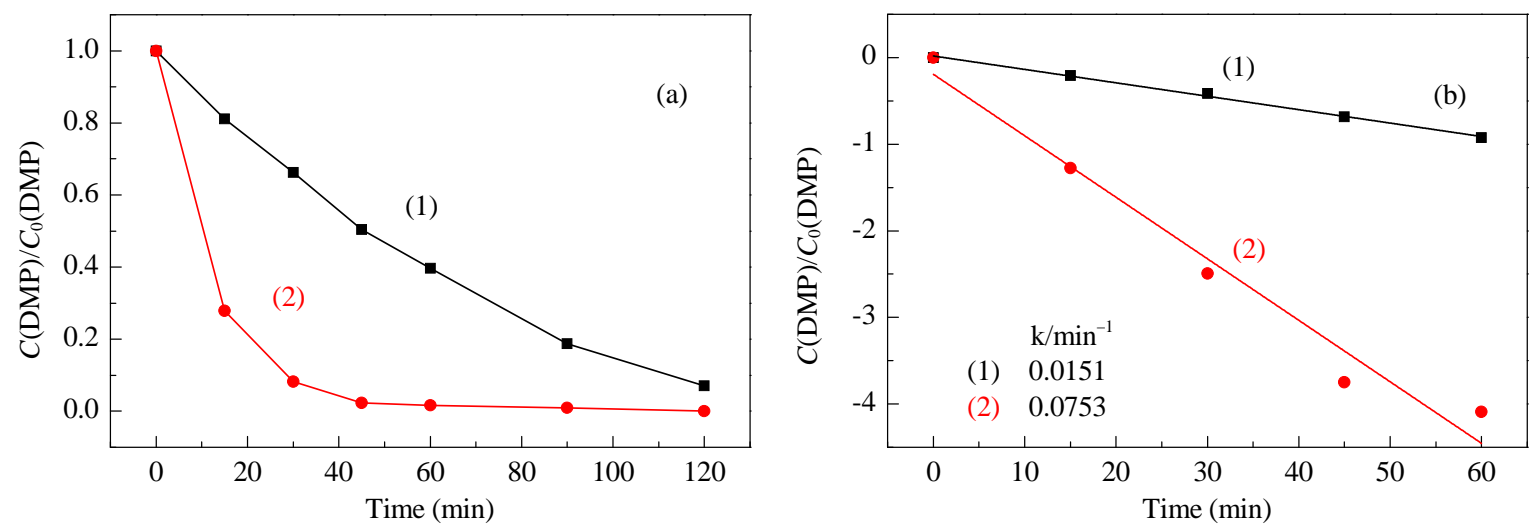

Fig. 3. DMP degradation of electro-Fenton systems using GF (1) and PANI @GF (2) as cathode. $C_{0}(\mathrm{DMP})=50 \mathrm{mg} / \mathrm{L}, U=0.5 \mathrm{~V}(v s . \mathrm{SCE}), V\left(\mathrm{O}_{2}\right)=0.4$ $\mathrm{L} / \mathrm{min}$.

DMP. This indicates that the DMP degradation performance of the E-Fenton system could be significantly enhanced using the PANI@GF cathode. According to some reports [34], the atomic $\mathrm{O}$ content of graphite felt increases after treatment by chemical or electrochemical methods. It is generally believed that an increase in oxygen containing functional groups is the main reason for the improvement of modified GF. In this work, the atomic 0 content of the PANI@GF electrode was lower than that of the GF electrode, suggesting that it was not the oxygen functional groups but the macroscopic and microscopic porous structure and the $\mathrm{N}$ atom doping that enhanced the DMP degradation performance of the E-Fenton system with PANI@GF cathode.

The degradation conditions had a significant influence on the performance of the PANI@GF cathode, so the optimum conditions for DMP degradation were further studied. The carbonization temperature is important for the structure of the PANI@GF surface. Within a certain temperature range, the DMP degradation ability of PANI@GF was gradually improved as the carbonization temperature was increased (Fig. 4). PANI@GF treated at $900{ }^{\circ} \mathrm{C}$ had the strongest DMP degradation ability. This enhancement might be attributed to the higher carbonization temperature causing the polyaniline on the sur-

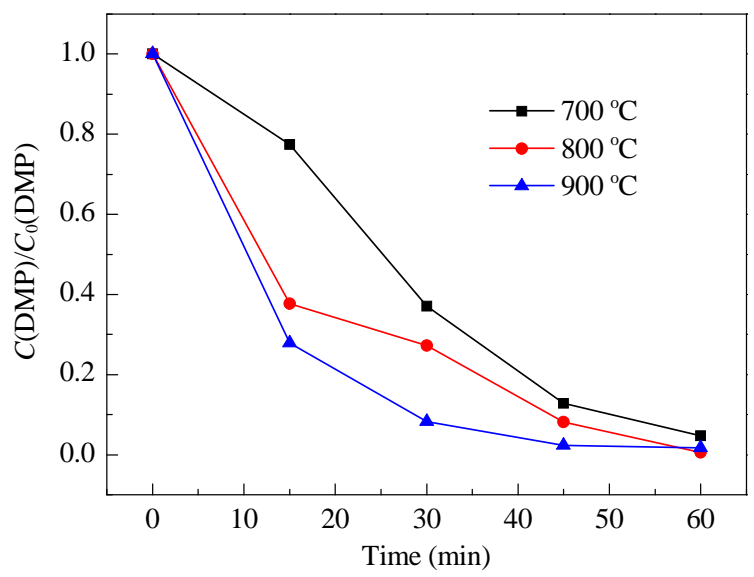

Fig. 4. DMP degradation of E-Fenton system using PANI@GF carbonized at different temperatures $\left({ }^{\circ} \mathrm{C}\right) . C_{0}(\mathrm{DMP})=50 \mathrm{mg} / \mathrm{L}, U=0.5 \mathrm{~V}(v s$. $\mathrm{SCE}), V\left(\mathrm{O}_{2}\right)=0.4 \mathrm{~L} / \mathrm{min}$. face of GF to form a looser and more porous structure. This would have improved the $\mathrm{O}_{2}$ mass transfer process and thus the DMP degradation performance of the cathode.

Just like the carbonization temperature, the polymerization time also affected the surface structure of PANI@GF. As shown in Fig. 5, the DMP degradation performance of GF alone was not good. After $1 \mathrm{~h}$ reaction $40 \%$ DMP still remained. When the electro-polymerization time was $1 \mathrm{~h}$, it took only $45 \mathrm{~min}$ to completely degrade DMP at the PANI@GF cathode. When the electro-polymerization time was extended to $2 \mathrm{~h}$, however, the ability of the cathode to degrade DMP declined. This behavior can be explained as follows: when the polymerization time is too short, polyaniline cannot adhere well to GF. In contrast, when the polymerization is too long, the resulting thick polyaniline layer could seal the micro pores on the surface of the GF and consequently hinder the diffusion of $\mathrm{O}_{2}$, which would cause the DMP degradation performance of the composite to deteriorate.

The DMP degradation conditions, including $\mathrm{O}_{2}$ flow rate, $\mathrm{Fe}$ concentration and $\mathrm{pH}$ value, were also studied. The DMP degradation performance of the composite under different $\mathrm{O}_{2}$ flow rates is shown in Fig. 6. When no $\mathrm{O}_{2}$ purge of the reaction cell was carried out, only $20 \%$ of the DMP was degraded in $1 \mathrm{~h}$.

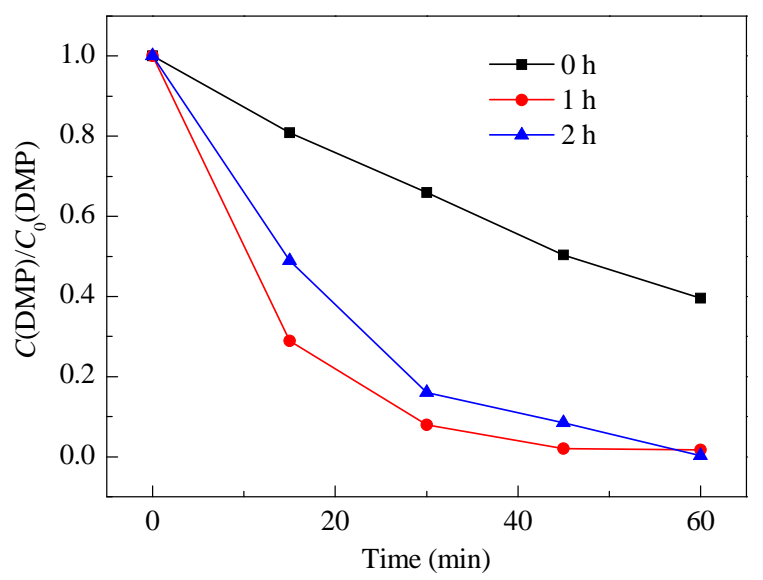

Fig. 5. DMP degradation of E-Fenton system using PANI@GF polymerized for different time (h). $C_{0}(\mathrm{DMP})=50 \mathrm{mg} / \mathrm{L}, U=0.5 \mathrm{~V}$ (vs. SCE), $V\left(\mathrm{O}_{2}\right)$ $=0.4 \mathrm{~L} / \mathrm{min}$. 


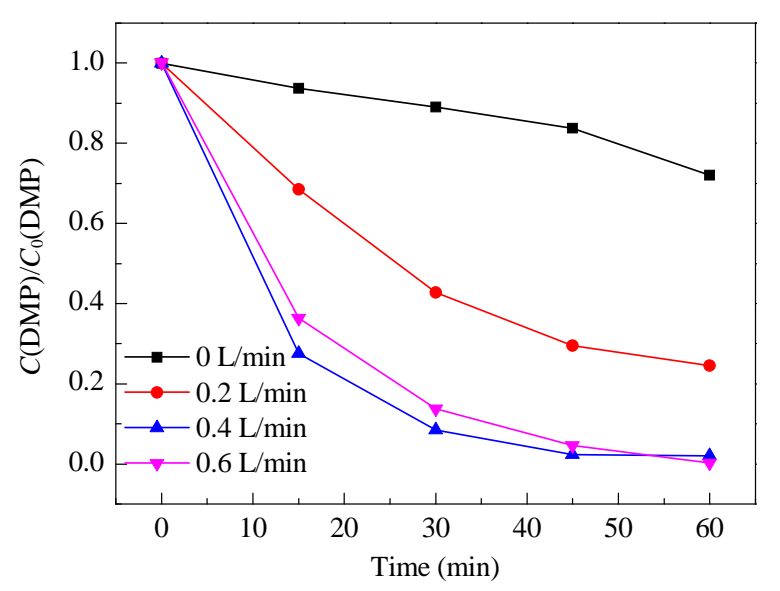

Fig. 6. DMP degradation of E-Fenton system using PANI@GF at different $\mathrm{O}_{2}$ flow rates $(\mathrm{L} / \mathrm{min}) . C_{0}(\mathrm{DMP})=50 \mathrm{mg} / \mathrm{L}, U=0.5 \mathrm{~V}(v s . \mathrm{SCE}), V\left(\mathrm{O}_{2}\right)$ $=0.4 \mathrm{~L} / \mathrm{min}$.

When the $\mathrm{O}_{2}$ flow rate was increased to $0.2 \mathrm{~L} / \mathrm{min}$, the DMP degradation performance was significantly improved. This is because when no $\mathrm{O}_{2}$ was fed into the cathode, the concentration of $\mathrm{O}_{2}$ dissolved in the solution was low, and the ORR was limited. When the $\mathrm{O}_{2}$ flow rate was increased, the DMP degradation performance was accordingly improved. However, the DMP degradation rate observed at $\mathrm{O}_{2}$ flow rate of $0.6 \mathrm{~L} / \mathrm{min}$ was slower than that at $0.4 \mathrm{~L} / \mathrm{min}$. As the $\mathrm{O}_{2}$ flow rate was increased, the ORR rate-limiting step changed from $\mathrm{O}_{2}$ concentration to $\mathrm{O}_{2}$ diffusion. The concentration of $\mathrm{O}_{2}$ in the solution reached its maximum value when the $\mathrm{O}_{2}$ flow rate was $0.4 \mathrm{~L} / \mathrm{min}$. Subsequently, increasing the flow rate beyond $0.4 \mathrm{~L} / \mathrm{min}$ could not further increase the $\mathrm{O}_{2}$ concentration. On the contrary, bubbles generated by the larger flow rate scoured the PANI surface, resulting in a decline in DMP degradation performance. Hence, the $0.4 \mathrm{~L} / \mathrm{min}_{2}$ flow rate was the optimal one.

The influence of $\mathrm{Fe}^{2+}$ concentration on DMP degradation is shown in Fig. 7. Varying the Fe (II) concentration had little influence on the DMP degradation results at $\mathrm{pH}=3.0$. This might be attributable to the fact that Fe (II) can be recycled through a

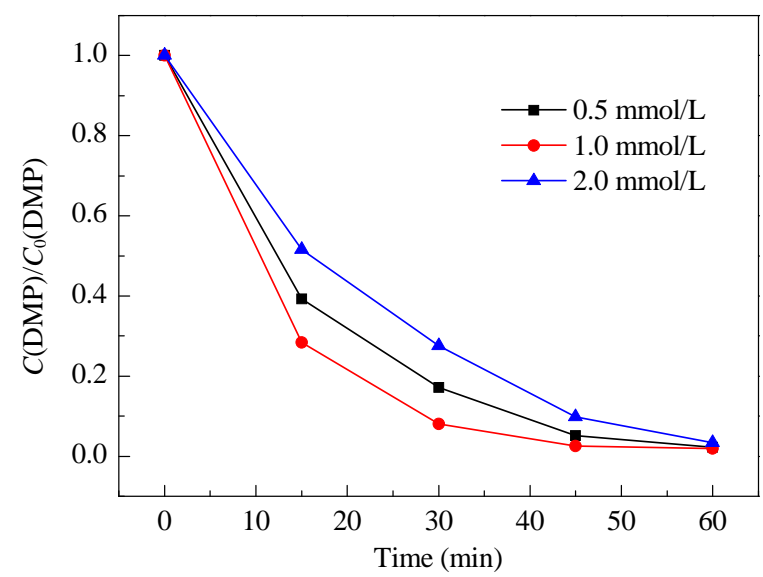

Fig. 7. DMP degradation of E-Fenton system using PANI@GF at different $\mathrm{Fe}^{2+}$ concentrations (mmol/L). $C_{0}(\mathrm{DMP})=50 \mathrm{mg} / \mathrm{L}, U=0.5 \mathrm{~V}$ (vs. $\mathrm{SCE}), V\left(\mathrm{O}_{2}\right)=0.4 \mathrm{~L} / \mathrm{min}$. variety of paths in the E-Fenton system. Furthermore, Fe (III) can also be reduced to Fe (II) at the cathode. As a result, 1.0 $\mathrm{mmol} / \mathrm{L}$ Fe (II) was sufficient for DMP degradation in this system.

The $\mathrm{pH}$ plays a fundamental role in the E-Fenton system. As depicted in Fig. 8, a pH of 3.0 was optimal for the present system, consistent with the 2.0-3.0 range for the E-Fenton system and that of conventional Fenton systems [35]. Under neutral or near neutral conditions, the DMP degradation performance was very poor, which might stem from a lack of $\mathrm{Fe}^{2+}$ [36]. The $\mathrm{pH}$ of the system can affect the chemical form of Fe. When the $\mathrm{pH}$ is greater than 4.0, $\mathrm{Fe}$ exists in the form of hydroxides such as $[\mathrm{Fe}(\mathrm{OH})]^{2+},\left[\mathrm{Fe}(\mathrm{OH})_{2}\right]^{+}$, and $\left[\mathrm{Fe}_{2}(\mathrm{OH})_{2}\right]^{4+}$. This leads to the precipitation of ferric hydroxides, hindering the conversion to $\mathrm{Fe}^{2+}$ and resulting in poor performance. Additionally, as a weak acid, $\mathrm{H}_{2} \mathrm{O}_{2}$ decomposes easily at higher $\mathrm{pH}$, which is inimical to DMP degradation.

\section{Conclusions}

A novel three-dimensional porous composite PANI@GF electrode was successfully prepared and employed for DMP degradation in aqueous solution. The PANI@GF electrode had both a macro and micro three-dimensional porous structure and was successfully doped with nitrogen atoms, which are beneficial for $\mathrm{O}_{2}$ diffusion and ORR to electrochemically generate $\mathrm{H}_{2} \mathrm{O}_{2}$. The apparent rate constant for DMP degradation at the PANI@GF cathode was 0.0753 min $^{-1}$, five times higher than that for the unmodified graphite felt cathode. It is believed that the macroscopic and microscopic porous structure and the $\mathrm{N}$ doping of PANI@GF enhanced its ORR performance. The optimal carbonization temperature and electro-polymerization time were $900^{\circ} \mathrm{C}$ and $1 \mathrm{~h}$, respectively. Both factors affected the structure of the PANI@GF electrode, and thus its DMP degradation performance. Higher carbonization temperature facilitated the formation of a looser microscopic pore structure that likely improved $\mathrm{O}_{2}$ diffusion. The $\mathrm{pH}$ of the system was found to be of crucial importance for DMP degradation, and the optimal value was 3.0. A suitable $\mathrm{O}_{2}$ flow rate was beneficial to DMP performance, and was found to be optimal at $0.4 \mathrm{~L} / \mathrm{min}$. Because $\mathrm{Fe}^{2+}$

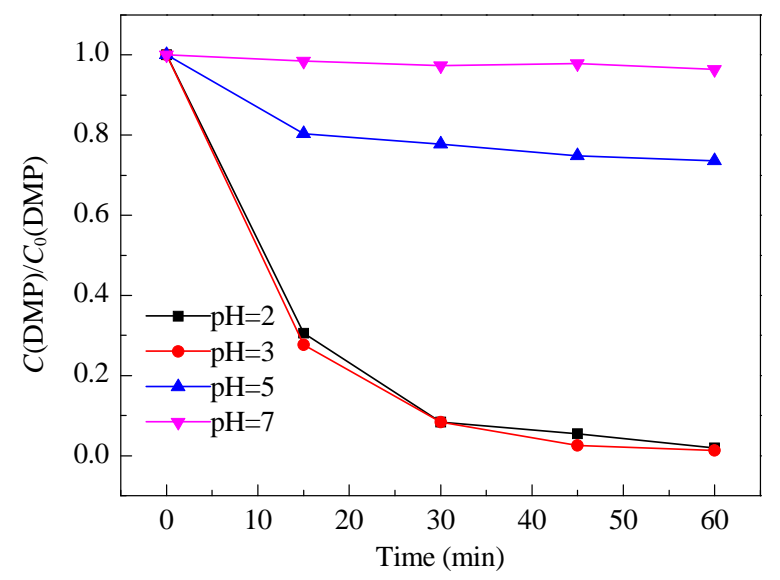

Fig. 8. DMP degradation of E-Fenton system using PANI@GF at different pH. $C_{0}(\mathrm{DMP})=50 \mathrm{mg} / \mathrm{L}, U=0.5 \mathrm{~V}(v s . \mathrm{SCE}), V\left(\mathrm{O}_{2}\right)=0.4 \mathrm{~L} / \mathrm{min}$. 


\title{
Graphical Abstract
}

Chin. J. Catal., 2016, 37: 2079-2085 doi: 10.1016/S1872-2067(16)62525-1

Electro-polymerization fabrication of PANI@GF electrode and its energy-effective electrocatalytic performance in electro-Fenton process

Jinli Yu, Tianfu Liu, Haiyue Liu, Yi Wang* Sun Yat-sen University

An energy-effective polyaniline coated graphite felt (PANI@GF) composite cathode was successfully synthesized through an electro-polymerization method, exhibiting desirable performance for dimethyl phthalate (DMP) degradation through electro-Fenton (E-Fenton) Process.
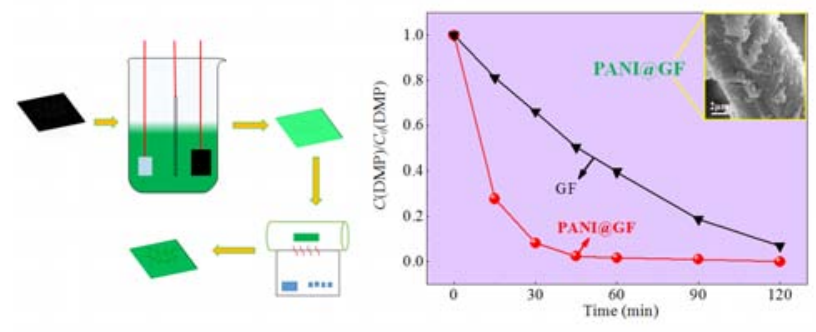

can be recycled through a variety of paths in the E-Fenton system, a concentration of $1.0 \mathrm{mmol} / \mathrm{L}$ was adequate. PANI@GF is an attractive alternative cathode for E-Fenton systems applied to the degradation of organic contaminants in wastewater.

\section{References}

[1] C. K. Duesterberg, S. E. Mylon, T. D. Waite, Environ. Sci. Technol., 2008, 42, 8522-8527.

[2] C. K. Duesterberg, T. D. Waite, Environ. Sci. Technol., 2006, 40, 4189-4195.

[3] S. Navalon, A. Dhakshinamoorthy, M. Alvaro, H. Garcia, ChemSusChem, 2011, 4, 1712-1730.

[4] J. J. Pignatello, E. Oliveros, A. MacKay, Crit. Rev. Environ. Sci. Technol., 2006, 36, 1-84.

[5] E. Brillas, I. Sirés, M.A. Oturan, Chem. Rev., 2009, 109, 6570-6631.

[6] A. Akyol, O. T. Can, E. Demirbas, M. Kobya, Sep. Purif. Technol., 2013, 112, 11-19.

[7] A. El-Ghenymy, F. Centellas, R. M. Rodríguez, P. L. Cabot, J. A. Garrido, I. Sirés, E. Brillas, Electrochim. Acta, 2015, 182, 247-256.

[8] A. Özcan, Y. Şahin, M.A. Oturan, Water Res., 2013, 47, 1470-1479.

[9] M. Panizza, A. Dirany, I. Sirés, M. Haidar, N. Oturan, M. A. Oturan, J. Appl. Electrochem., 2014, 44, 1327-1335.

[10] S. Ammar, M. A. Oturan, L. Labiadh, A. Guersalli, R. Abdelhedi, N. Oturan, E. Brillas, Water Res., 2015, 74, 77-87.

[11] E. Brillas, E. Mur, R. Sauleda, L. Sànchez, J. Peral, X. Domènech, J. Casado, Appl. Catal. B, 1998, 16, 31-42.

[12] A. M. F. M. Guedes, L. M. P. Madeira, R.A.R. Boaventura, C. A. V. Costa, Water Res., 2003, 37, 3061-3069.

[13] E. Mousset, N. Oturan, E. D. van Hullebusch, G. Guibaud, G. Esposito, M. A. Oturan, Appl. Catal. B., 2014, 160-161, 666-675.

[14] H. Liu, C. Wang, X. Li, X. L. Xuan, C. C. Jiang, H. N. Cui, Environ. Sci. Technol., 2007, 41, 2937-2942.

[15] H. Liu, X. Li, Y. Leng, C. Wang, Water Res., 2007, 41, 1161-1167.

[16] E. Rosales, M. Pazos, A. Sanroman, M. Angeles, Chem. Eng. Technol., 2012, 35, 609-617.
[17] C. T. Wang, J. L. Hu, W. L. Chou, Y. M. Kuo, J. Hazard. Mater., 2008, 152, 601-606.

[18] M. H. M. T. Assumpcao, R. F. B. De Souza, D. C. Rascio, J. C. M. Silva, M. L. Calegaro, I. Gaubeur, T. R. L. C. Paixão, P. Hammer, M. R. V. Lanza, M. C. Santos, Carbon, 2011, 49, 2842-2851.

[19] S. H. Yuan, M. Tian, Y. P. Cui, L. Lin, X. H. Lu, J. Hazard. Mater., 2006, 137, 573-580.

[20] M. A. Oturan, J. Peiroten, P. Chartrin, A. J. Acher, Environ. Sci. Technol., 2000, 34, 3474-3479.

[21] M. Panizza, G. Cerisola, Water Res., 2001, 35, 3987-3992.

[22] A. Özcan, Y. Şahin, A. Savaş Koparal, M. A. Oturan, J. Electroanal. Chem., 2008, 616, 71-78.

[23] A. M. Wang, J. H. Qu, J. Ru, H. J. Liu, J. T. Ge, Dyes Pigments, 2005, 65, 227-233.

[24] M. Panizza, G. Cerisola, Water Res., 2009, 43, 339-344.

[25] M. H. Zhou, Q. H. Yu, L. C. Lei, G. Barton, Sep. Purif. Technol., 2007, 57, 380-387.

[26] Y. Wang, Y. H. Liu, K. Wang, S. Q. Song, P. Tsiakaras, H. Liu, Appl. Catal. B., 2015, 165, 360-368.

[27] C. L. Han, J. T. Wang, Y. T. Gong, X. Xu, H. R. Li, Y. Wang, J. Mater. Chem. A., 2014, 2, 605-609.

[28] E. Cruz-Silva, F. Lopez-Urias, E. Munoz-Sandoval, B. G. Sumpter, H. Terrones, J. C. Charlier, V. Meunier, M. Terrones, Nanoscale, 2011, 3, 1008-1013.

[29] J. I. Ozaki, N. Kimura, T. Anahara, A. Oya, Carbon, 2007, 45, 1847-1853.

[30] G. Wu, K. L. More, C. M. Johnston, P. Zelenay, Science, 2011, 332, 443-447.

[31] S. J. Kim, K. S. Nahm, P. Kim, Catal. Lett., 2012, 142, 1244-1250.

[32] B. L. Yuan, X. Z. Li, N. Graham, Water Res., 2008, 42, 1413-1420.

[33] B. L. Yuan, X. Z. Li, N. Graham, Chemosphere, 2008, 72, 197-204.

[34] Y. Li, Y. Z. Fang, H. Liu, X. M. Wu, Y. Lu, Nanoscale, 2012, 4, 2867-2869.

[35] J. J. Pignatello, Environ. Sci. Technol., 1992, 26, 944-951.

[36] R. Z. Chen, J. J. Pignatello, Environ. Sci. Technol. 1997, 31, 2399-2406.

\section{电聚合制备聚苯胺@石墨毡复合电极及其在电芬顿过程中的高效电催化性能}

\author{
余金礼 ${ }^{\mathrm{a}}$, 刘天夫 ${ }^{\mathrm{b}}$, 刘海越 ${ }^{\mathrm{b}}$ ，王 毅 ${ }^{\mathrm{b}, *}$ \\ $\mathrm{a}$ 广东省低碳化学与过程节能重点实验室, 中山大学材料科学与工程学院, 广东广州510275 \\ b山大学化学工程与技术学院, 广东珠海519082
}

摘要: 作为一种高级氧化技术 (AOPs), 芬顿氧化法 (Fenton) 因其操作简单、绿色高效而备受关注. 其基本原理是 $\mathrm{Fe}^{2+}$ 催化 
$\mathrm{H}_{2} \mathrm{O}_{2}$ 产生的差基自由基 $(\cdot \mathrm{OH})$ 进攻有机物使之降解为无机小分子或盐. 电芬顿法 (Electro-Fenton, E-Fenton) 是利用电化 学方法原位生成 $\mathrm{H}_{2} \mathrm{O}_{2}$ 的 Fenton 衍生法, 其优点在于不需要从外界加入 $\mathrm{H}_{2} \mathrm{O}_{2}$ 、高效节能、无选择性、并且易于和其他处理 技术耦合, 是一种非常有价值和应用前景的新型水处理技术. 电芬顿技术的理论探究和工艺优化, 是当今高级氧化技术的 理论和实践研究的重要内容. E-Fenton 过程的关键步骤是阴极材料上氧还原反应 (Oxygen reduction reaction, ORR) 持续生 成 $\mathrm{H}_{2} \mathrm{O}_{2}$. 由于析氢过电位高、稳定性好、性能优异, 碳材料成为 ORR 反应最常用的电催化阴极材料. 石墨毛作为一种三 维多孔立体材料, 具有电化学活性面积大、传质好、导电性强、价格低等优点, 是 ORR 的理想阴极材料. 聚苯胺材料作为 一种导电高分子材料, 价格便宜、加工性好、且含有丰富的 $\mathrm{N}$ 原子, 在基础研究和实际应用领域都十分活跃. 我们创新性 地采用电聚合的方法合成了聚苯胺@石墨钻 (PANI@GF) 复合电极, 并通过降解邻苯二甲酸二甲酯 (dimethyl phthalate, DMP) 研究了其在电芬顿过程中的电催化性能.

通过扫描电镜、X 射线光电子能谱分析对电极表面结构和杂原子掺杂性进行了物化表征. 结果显示 PANI@GF 复合电 极同时具有宏观和微观的三维多孔结构, 这种结构蓬松的多孔结构为氧气提供了合适的传递通道和足够的反应面积. 所 制备复合电极中 $\mathrm{N}$ 原子含量约为 $1.9 \%$, 且吡啶 $\mathrm{N}$ 和吡咯 $\mathrm{N}$ 的含量相对较高. 这些 $\mathrm{N}$ 原子来自聚苯胺分子中含有的大量 $\mathrm{N}$ 原子, 并能够促进 ORR 反应. 石墨毡和聚苯胺两种材料的在结构和组分上的特点, 使得 PANI@GF 复合电极具有优异 的电芬顿降解 DMP 的性能. 在 DMP 浓度为 $50 \mathrm{mg} / \mathrm{L}$ 、电位 $0.5 \mathrm{~V}(\mathrm{vs}$. SCE)、氧气流速为 $0.4 \mathrm{~L} / \mathrm{min}$ 的条件下, 其 DMP 降解 反应表观动力学常数达 $0.0753 \mathrm{~min}^{-1}$, 是石墨毡电极表观动力学常数 $\left(0.0151 \mathrm{~min}^{-1}\right)$ 的 5 倍.

PANI@GF 复合电极制备的最优聚合时间和碳化温度分别为 $1 \mathrm{~h}$ 和 $900{ }^{\circ} \mathrm{C}$. 这是因为聚合时间太长, 可能导致聚苯胺 层厚度大, 微孔结构被堵塞, 进而降低了反应活性面积和影响氧气传质效果, 使得电极性能下降; 而聚合时间太短, 可能导 致电极复合不充分. 高温碳化可以使石墨䏨表面聚苯胺层形成更多的孔结构, 从而有利于 ORR 过程.

DMP 降解过程中氧气流速、 $\mathrm{Fe}^{2+}$ 用量以及 $\mathrm{pH}$ 值等工艺条件对电极性能有一定的影响, 结果表明其相应的优化值分别 为 $0.4 \mathrm{~L} / \mathrm{min} 、 1.0 \mathrm{mmol} / \mathrm{L}$ 和 3.0. 当氧气流速过低时, 溶液中低浓度的溶解氧使 ORR 过程受传质过程限制, 导致电极不能 充分反应; 当氧气流速过大时, 并不会增加已经达到饱和的溶液中的氧气浓度, 而过大的氧气速率会冲击电极表面, 降低 电极稳定性而影响其催化性能. 对 $\mathrm{Fe}^{2+}$. 用量而言, E-Fenton 过程有多种 Fe 循环途径, 不同的铁含量对于电极性能影响不 明显. 因此, $1.0 \mathrm{mmol} / \mathrm{L}$ 的 Fe 含量足够满足实验需要. $\mathrm{pH}$ 值对 E-Fenton 过程至关重要, $\mathrm{pH}$ 较高时, 铁离子会形成配合物, 阻碍铁循环, 并且会导致 $\mathrm{H}_{2} \mathrm{O}_{2}$ 的分解, 从而降低电极 DMP 降解性能; 而当 $\mathrm{pH}$ 太低时, 较多的酸增加成本, 且需要后续处 理过程以消除酸的影响. 实验结果表明 3.0 是最优 $\mathrm{pH}$ 值, 与传统 Fenton 方法的最适 $\mathrm{pH}$ 相符. PANI@GF 复合电极具有 高效催化降解 DMP 的能力, 在电芬顿技术处理有机废水中有潜在应用.

关键词: 电催化; 氧还原; 电聚合; 电芬顿; DMP 降解

收稿日期: 2016-08-18. 接受日期: 2016-09-08. 出版日期: 2016-12-05.

*通讯联系人. 电话: (020)84110930; 传真: (020)84113253; 电子信箱: wangyi76@mail.sysu.edu.cn

基金来源：科技部政府间科技合作项目 (2013DFG62590); 国家自然科学基金 (21575299, 21576300, 21276290); 广东省自然科学 基金 (2014A030313150); 广州市科技计划项目 (201607010104).

本文的英文电子版由Elsevier出版社在ScienceDirect上出版(http://www.sciencedirect.com/science/journal/18722067). 